\title{
THE CORRELATION BETWEEN LEVEL OF ANXIETY DURING COVID-19 PANDEMIC AND THE INCIDENCE OF PRIMARY DYSMENORRHOEA IN FEMALE ADOLESCENTS AT SMAN 1 SINDANG INDRAMAYU IN 2020
}

\author{
Deysi Rizky Al Fharizy, Nurasih, Nina Nirmaya Mariani \\ Poltekkes Kemenkes Tasikmalaya \\ deysirizky.9d@gmail.com
}

\begin{abstract}
Female adolescents who experience anxiety will have an increase in prostaglandin synthesis accompanied by decreased levels of estrogen or progesterone, causing uterine muscle contractions, uterine blood flow, uterine ischemia resulting in dysmenorrhea. The prevalence of dysmenorrhoea varies between $15.8 \%-89.5 \%$, with the highest prevalence in adolescents, this shows that adolescents are very vulnerable to anxiety which will lead to the incidence of dysmenorrhoea. This study aims to determine the correlation between the level of anxiety during the Covid-19 pandemic and the incidence of primary dysmenorrhoea in adolescents at SMAN 1 Sindang Indramayu in 2020. Non-experimental research with correlational analytic design with cross sectional approach using primary data of 50 female adolescents who were taken by quota sampling technique. Collecting data using an electronic questionnaire which is analyzed by the Spearman rank test.

In the univariate analysis, $36 \%$ of 50 female adolescents had mild anxiety and $72 \%$ had mild primary dysmenorrhoea. Bivariate analysis with the Spearman rank statistical test obtained significance or $\mathrm{P}$ value $=0.003<0.05$ and a correlation coefficient value of 0.418 and is positive.

There are correlation between the level of anxiety during Covid-19 pandemic and the incidence of primary dysmenorrhoea in female adolescents at SMAN 1 Sindang Indramayu with the strength of the correlation between two variables in the sufficient category and positive, which means that if the variable level of anxiety is high, the primary dysmenorrhoea variable is getting higher.
\end{abstract}

Keywords: anxiety, primary dysmenorrhea, female adolescent 


\section{Introduction}

Puberty is a period of transition from children to adults (adolescence) (BKKBN, 2019). Puberty begins at the age of $8-14$ years (BKKBN, 2016). The physical changes that occur during puberty are important events, take place quickly and drastically, are irregular and occur in the reproductive system. Hormones begin to be produced and affect the reproductive organs to start the reproductive cycle and with the gradual development of primary sexual characteristics and secondary sexual characteristics, adolescent girls are marked by menarche (first menstruation). (Lubis, 2016). Menstruation is the release of the uterine wall (endometrium) where an unfertilized egg will come out along with the collapse of the thickened uterine wall marked by bleeding and occurs every month except during pregnancy. Menstruation usually occurs at age 11 years and lasts for 5-7 days. Bleeding as much as 50-80 cc / day (changing pads 2-3 times per day), a normal menstrual cycle averages 28 days (21-35 days) (BKKBN, 2016).

During menstruation, complaints or disorders often arise, especially in productive women, especially in adolescents, which often occurs, namely menstrual pain or dysmenorrhoea. (Supriatin, 2014). Dysmenorrhoea is pain during menstruation felt in the lower abdomen or in the michaelic square area, pain felt before, during and after menstruation. Can be kholik or continuous (Lubis, 2016). The cause of dysmenorrhoea is thought to be due to spasms in the uterine muscles due to poor blood flow. Menstrual disorders occur 24 hours before menstruation comes and 12 hours during menstruation or menstruation, about $50 \%$ of women experience menstrual disorders and reach their peak at the age of 17-25 years. Dysmenorrhoea is divided into 2, namely primary dysmenorrhoea (no relationship with gynecologic disorders) and secondary dysmenorrhoea (caused by gynecologic disorders) (Harnani et al., 2015).

Research by dr. Cakir M. et al, found that dysmenorrhoea is a menstrual disorder with a prevalence of $89.5 \%$, followed by menstrual irregularities $31.25 \%$, and an extension of menstrual duration of 5.3\% (DEPKES, 2011). In Indonesia, the incidence of dysmenorrhea is quite high, showing that people with dysmenorrhea reach $60-70 \%$ of women in Indonesia. 
The incidence rate of primary type dysmenorrhoea in Indonesia is $54.89 \%$, while the remaining $45.11 \%$ are secondary types (Lail Husnul, 2017). Based on the results of (Narulita, 2012), the incidence of dysmenorrhoea in West Java was quite high, the results showed that $54.9 \%$ of women had dysmenorrhoea, consisting of $24.5 \%$ having mild dysmenorrhoea, $21.28 \%$ having moderate dysmenorrhoea and 9, 36\% had severe dysmenorrhea (Rahayu, R., 2019). In a review of other studies, Bieniasz J. et al, found the prevalence of dysmenorrhea varies between 15.8\% - 89.5\%, with the highest prevalence in adolescents (Depkes RI, 2011).

The prevalence of dysmenorrhoea is quite high in adolescents, the impact of dysmenorrhea is a decrease in daily activities to the use of therapy. The risk factors for dysmenorrhea are not only related to physiological factors but also psychological factors including anxiety (Calis, 2012).

In a study conducted by Supriatina on students of SMP X Bandung in 2014, it showed that almost all students tended to experience anxiety, namely $93.5 \%$ which stated dysmenorrhoea, so this study concluded that there was a significant relationship between adolescent anxiety and the incidence of dysmenorrhoea. The results of this study are in line with research conducted by Sukmati and Khairunnisa in 2017 with data on the incidence of dysmenorrhoea in class VII students at SMPN 1 Ciwidey showing a severe level of anxiety $(40.3 \%)$ and those experiencing dysmenorrhoea (54.2\%), in this study there was a significant positive relationship and had a moderate strength correlation between the level of anxiety and the incidence of dysmenorrhoea and showed that the higher the level of anxiety caused dysmenorrhoea in young women.

According to the calculation of disease burden in 2017, several types of mental disorders that are predicted to be experienced by residents in Indonesia include depression, anxiety, schizophrenia, bipolar disorder, behavioral disorders, autism, eating behavior disorders, intellectual disabilities, Attention Deficit Hyperactivity Disorder (ADHD). In a period of three decades (1990-2017), there was a change in the pattern of mental illness, which experienced an increase in DALYs including schizophrenia, bipolar disorder, autism, and eating disorders. Depression and anxiety disorders remain number one and second place respectively in the three decades of the Institute for Health metrics and evaluation (IHME) 2017 (Pusat Data dan Informasi Kementrian Kesehatan RI, 2019). (Pusat Data dan Informasi Kementrian RI, 2019) The results of a study by Michael and Fombon 2005 stated that all the 
disorders experienced by adolescence were the greatest anxiety disorders compared to adult anxiety. This shows that at least teenagers are very vulnerable to anxiety (Mardjan, 2016).

Anxiety is worry, fear for which it is not clear. Anxiety or anxiety can be generated by external danger, possibly from within a person, and generally the threat is subtle. Danger from within, arises when there are things that cannot be accepted, for example thoughts, feelings, desires, and impulses (Chrisnawati, 2019).

Anxiety arises as a result of a response to stress or conflict conditions. This is commonplace where a person experiences changes in situations in his life and is required to be able to adapt. Anxiety is very familiar with human life which describes worry, anxiety, fear and a sense of uneasiness which is usually associated with the threat of danger both from within and from outside the individual. Anxiety is a normal symptom in humans and is called pathological if the symptoms persist for a certain period of time and disturb the peace of the individual. Anxiety is very disturbing the homeostasis and individual function, therefore it needs to be eliminated by various means of adjustment (Achmad \& Sukohar, 2019).

Ida Rochmawati, M.Sc., Sp.Kj., explained directly in the webinar that: "Talking about anxiety, actually at this time during the COVID-19 pandemic everyone is anxious of all ages, not only teenagers, as well as parents, circles and professions, even now we are experiencing anxiety in congregation. Especially for adolescents, why is it important for us to talk about being anxious because in the future we will face a demographic bonus, and it will be a burden if adolescent anxiety is not managed properly, while these teenagers will become the occupants of the demographic bonus. Mentally and emotionally, the prevalence of mental disorders at the age of more than 15 years is $9.8 \%$ and this data is increasing compared to 2013 based on the results of riskesdas. Anxiety in adolescents occurs around 20\% of adolescents aged 13-18 years (National Institute of Health-US) and as many as 7-10 adolescents aged 13-17 years say that anxiety and depression are the main problems". (UGM, F, 2020).

Adolescents who experience anxiety or stress will experience an increase in prostaglandin synthesis accompanied by decreased levels of estrogen or progesterone, then uterine muscle contractions, uterine blood flow, uterine ischemia resulting in menstrual pain or dysmenorrhea (Supriatin, 2014). 
A preliminary study conducted by researchers on 21-23 June 2020 using a questionnaire on google form filled out by 12 young women at SMAN 1 Sindang, showed that all had primary dysmenorrhoea (100\%), 10 of them had severe dysmenorrhoea (83\%) and 2 other girls had moderate dysmenorrhea (17\%). These findings indicate a high incidence of dysmenorrhoea in adolescent girls at SMAN 1 Sindang Indramayu. Also obtained from the 12 female teenagers, 2 of them experienced mild anxiety (17\%), 2 teenagers moderate anxiety (17\%), and 8 other teenagers $(66 \%)$ did not experience anxiety. Based on this description, anxiety during the COVID-19 pandemic is suspected to be related to the incidence of dysmenorrhea (DPL \& Gustaman, n.d.) declared that: “ The Coronavirus pandemic threatens not only physical health, but also mental health of every individual. Not only fear, but the psychological effects it can cause can have serious consequences".

\section{Method}

This study is a non-experimental study with a correlational analytical research design using a cross-sectional approach, to determine the relationship between anxiety levels during the COVID-19 pandemic and the incidence of primary dysmenorrhoea. This research was conducted at SMAN 1 Sindang Indramayu which was held from May to December 2020. The population in this study were all girls in class XI of the Mathematics and Natural Sciences program at SMAN 1 Sindang, Indramayu Regency, totaling 140 students who had menarche and experienced primary dysmenorrhoea, with a sample of 50 students who met the inclusion and exclusion criteria. The sampling technique in this study used a non-probability sampling technique with quota sampling. Data collection in this study used an electronic questionnaire, the questionnaire was made on google form because many cases were confirmed positive for COVID-19 in Indramayu, during the COVID-19 pandemic, electronic research questionnaires made with google form and giving the questionnaire link to respondents would be more effective and efficient to collect data by minimizing contact with respondents and avoiding large mass gatherings so as to help curb the spread of the virus. The instrument used to measure the value of the independent variable level of anxiety during the COVID-19 pandemic in this study is the Depression Anxiety Stress Scale (DASS). In the dependent variable dysmenorrhoea in adolescent girls, researchers used a dysmenorrhoea questionnaire. 
Data analysis includes univariate analysis which aims to describe the characteristics of each research variable, as well as bivariate analysis using the spearman rank test (Dahlan, 2015).

\section{Results}

Table 1. Frequency Distribution of Female Adolescent by Age at SMAN 1 Sindang Indramayu in 2020

\begin{tabular}{lccc}
\hline & Characteristics & Frequency & Percentage \\
\hline & 15 years old & 1 & $2 \%$ \\
& 16 years old & 35 & $70 \%$ \\
& 17 years old & 14 & $28 \%$ \\
\hline Total & 50 & $100 \%$ \\
\hline
\end{tabular}

Based on table 1, it can be seen that the age of female adolescents at SMAN 1 Sindang Indramayu which has the most frequency is 16 years as many as 35 students (70\%).

Table 2. Frequency Distribution of Female Adolescent Based on Menarche Experience at SMAN 1 Sindang Indramayu in 2020

\begin{tabular}{|c|c|c|}
\hline Characteristics & Frequency & Percentage \\
\hline \multirow{2}{*}{$\begin{array}{l}\text { Has Not Menarche Yet } \\
\text { Has Menarche }\end{array}$} & 0 & $0 \%$ \\
\hline & 50 & $100 \%$ \\
\hline Total & 50 & $100 \%$ \\
\hline
\end{tabular}

Based on table 2, all 50 female adolescents at SMAN 1 Sindang Indramayu have experienced menarche or have had their first menstruation $(100 \%)$. 
Table 3. Frequency Distribution of Female Adolescent Based on Anxiety Levels during the Covid-19 Pandemic at SMAN 1 Sindang Indramayu in 2020

\begin{tabular}{lccc}
\hline & Anxiety Level & Frequency & Percentage \\
\hline Normal & 23 & $46 \%$ \\
Mild & 18 & $36 \%$ \\
Moderate & 8 & $16 \%$ \\
Severe & 1 & $2 \%$ \\
Panic & 0 & 0 \\
\hline Total & 50 & $100 \%$ \\
\hline
\end{tabular}

Based on table 3, it shows that as many as 23 adolescents at SMAN 1 Sindang Indramayu did not experience anxiety (46\%) and the most anxiety levels during the Covid-19 Pandemic were experienced by students with mild anxiety with a frequency of 18 adolescents $(36 \%)$.

Table 4. Frequency Distribution of Female Adolescent Based on Primary Dysmenorrhoea Levels at SMAN 1 Sindang Indramayu in 2020

\begin{tabular}{|c|c|c|}
\hline Primary Dysmenorrhea & Frequency & Percentage \\
\hline Mild & 26 & $72 \%$ \\
\hline Moderate & 18 & $36 \%$ \\
\hline Severe & 6 & $12 \%$ \\
\hline Total & 50 & $100 \%$ \\
\hline
\end{tabular}

Based on table 4, it can be seen that most of the female adolescents at SMAN 1 Sindang Indramayu have mild dysmenorrhoea with a total of 26 students (72\%).

Table 5. Spearman rank statistical test

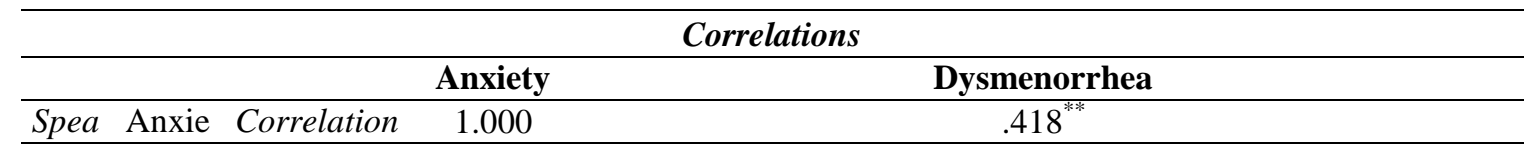




\begin{tabular}{|c|c|c|c|c|}
\hline \multirow{6}{*}{$\begin{array}{l}\text { rman' } \\
\text { s rho }\end{array}$} & \multirow{3}{*}{ ty } & \multicolumn{3}{|l|}{ Coefficient } \\
\hline & & $\begin{array}{l}\text { Sig. (2- } \\
\text { tailed) }\end{array}$ & $\cdot$ & .003 \\
\hline & & $\mathrm{N}$ & 50 & 50 \\
\hline & \multirow{3}{*}{$\begin{array}{l}\text { Dysm } \\
\text { enorr } \\
\text { hea } \\
\text { hea }\end{array}$} & $\begin{array}{l}\text { Correlation } \\
\text { Coefficient }\end{array}$ & $.418^{* * *}$ & 1.000 \\
\hline & & $\begin{array}{l}\text { Sig. }(2- \\
\text { tailed })\end{array}$ & .003 & - \\
\hline & & $\mathrm{N}$ & 50 & 50 \\
\hline
\end{tabular}

**. Correlation is significant at the 0.01 level (2-tailed).

Based on table 5, the results of the spearman rank statistical test obtained significance or $\mathrm{P}$ value $=0.003<0.05$ and a correlation coefficient value of 0.418 and is positive so it can be concluded that there is a relationship between anxiety levels during the Covid-19 pandemic and the incidence of primary dysmenorrhoea in female adolescents at SMAN 1 Sindang Indramayu. The spearman rank correlation coefficient value of 0.418 indicates that the strength of the relationship between these two variables is in the sufficient category and the two variables are unidirectional.

\section{Discussion}

Anxiety Level

Research conducted on female adolescent at SMAN 1 Sindang Indramayu using the DASS42 questionnaire from the respondents studied, the results showed that 18 female adolescent experienced mild anxiety (36\%), then followed by moderate anxiety as many as 8 female adolescent (16\%) and severe anxiety experienced by 1 female adolescent $(2 \%)$. From the results of the questionnaire analysis, female adolescents who experience anxiety are characterized by symptoms that are in accordance with the theory (Zaini, 2019), such as decreased concentration, feelings of worry, sadness, insecurity and confusion, decreased appetite, muscle tension, increased vital signs, trouble sleeping and pain. Then, there are behavioral changes that appear in people who experience anxiety such as decreased concentration, feelings of worry, sadness, insecurity and confusion, decreased appetite, muscle tension, increased vital signs, trouble sleeping and pain. Then, there are behavioral changes that appear in people who experience anxiety such as decreased productivity, 
increased alertness and insecurity. Social changes such as lack of initiative, difficulty enjoying daily activities and avoiding social contact.

Based on (Fudyartanta, 2012), anxiety disorders are more easily experienced by someone who is younger than individuals with an older age and women have a higher level of anxiety than men. This is because women are more sensitive to their emotions. Stressor is a demand for adaptation to individuals caused by changes in circumstances in life, the nature of stressors can change suddenly and can affect a person in dealing with anxiety. This is an internal factor that affects anxiety during the Covid-19 pandemic in young women at SMAN 1 Sindang Indramayu.

Primary Dysmenorrhea

There are 26 out of 50 girls at SMAN 1 Sindang Indramayu experiencing mild dysmenorrhoea (72\%), the remaining 18 girls (36\%) and 6 girls (12\%) respectively experienced moderate and severe dysmenorrhoea respectively. The results of the dysmenorrhoea questionnaire analysis showed that 26 young women with mild dysmenorrhoea were still able to carry out daily activities and were still able to concentrate even though they were painful, this is in accordance with (Manuaba, 2010), namely Mild dysmenorrhea is if the pain lasts for a while and only requires a short break and can continue daily activities so there is no need to use drugs, mild dysmenorrhea is accompanied by signs and symptoms such as being able to do activities and be able to concentrate on learning. During the Covid-19 pandemic, female adolescents must adapt to changing conditions in life that can affect a person in dealing with anxiety. Anxiety or stress will result in an increase in prostaglandin synthesis accompanied by a decrease in estrogen or progesterone levels, then uterine muscle contractions, uterine blood flow, uterine ischemia resulting in menstrual pain or dysmenorrhea (Supriatin, 2014).

The relationship between the level of anxiety during the Covid-19 pandemic with the incidence of primary dysmenorrhoea in young women at SMAN 1 Sindang Indramayu in 2020 , based on table 5, the spearman rank statistical test obtained a significance result or $\mathrm{P}$ value $=0.003<0.05$ and a correlation coefficient value of 0.418 and positive value, so it can be concluded that there is a relationship between the level of anxiety during the Covid-19 pandemic and the incidence of primary dysmenorrhoea in female adolescent at SMAN 1 Sindang Indramayu. The spearman rank correlation coefficient value of 0.418 indicates that 
the strength of the relationship between these two variables is in the sufficient category and the two variables are unidirectional. The results of this study are in line with the research conducted by Supriatina on students of SMP X Bandung in 2014 which showed that almost all students tended to experience anxiety, namely $93.5 \%$ who stated dysmenorrhoea, So this study concludes that there is a significant relationship between adolescent anxiety and the incidence of dysmenorrhoea. Supported by the results of research conducted by Sukmati and Khairunnisa in 2017 with data on the incidence of dysmenorrhoea in class VII students at SMPN 1 Ciwidey showing a severe level of anxiety (40.3\%) and those experiencing dysmenorrhoea (54.2\%) in this study. There is a significant positive relationship and has a moderate strength correlation between the level of anxiety and the incidence of dysmenorrhoea and shows that the higher the level of anxiety, the higher the incidence of dysmenorrhoea in female adolescents. Anxiety according to (Wuryaningsih, Emi Wuri., 2018) is a general or universal response experienced by individuals when facing stressors. Anxiety will be a problem if it interferes with adaptive behavior, causes physical symptoms and becomes severe for the individual (Wuryaningsih, Emi Wuri., 2018). Anxiety or stress will result in an increase in prostaglandin synthesis accompanied by a decrease in estrogen or progesterone levels, then uterine muscle contractions, uterine blood flow, uterine ischemia resulting in menstrual pain or dysmenorrhoea (Supriatin, 2014).

According to (Sinaga et al., 2017), primary dysmenorrhoea is caused by natural chemicals produced by cells lining the uterine wall called prostaglandins. Prostaglandins will stimulate the smooth muscles of the uterine wall to contract. The higher the prostaglandin level, the stronger the contractions. Other pain mechanisms are caused by prostaglandins (PGE2) and other hormones that make the painful sensory nerves in the uterus hypersensitive to the action of bradykinin and other physical and chemical pain stimuli (Reeder et al., 2013).

\section{Conclusion}

The majority of female adolescents at SMAN 1 Sindang Indramayu experience a mild level of anxiety. 
The majority of female adolescents at SMAN 1 Sindang Indramayu have mild levels of primary dysmenorrhoea.

There is a relationship between the level of anxiety during the Covid-19 pandemic and the incidence of primary dysmenorrhoea in female adolescent at SMAN 1 Sindang Indramayu, with the strength of the relationship between variables in the sufficient category and is unidirectional or positive, which means that if the variable level of anxiety is high, then the primary dysmenorrhoea variable is getting higher too.

\section{Suggestions}

The results of this study provide information and increase understanding and insight into the level of anxiety that occurred during the Covid-19 pandemic with the incidence of primary dysmenorrhoea in female adolescent, so it is suggested that female adolescent can be calmer in facing the Covid-19 pandemic, such as filtering the information obtained, so as not to cause anxiety, and divert fear or worry to positive things by adhering to health protocols every time you do activities.

Becoming one of the references for research sites in particular, in providing education to female adolescent about mental health through the Usaha Kesehatan Sekolah (UKS) program such as health education or provision of counseling, information and education, collaborating across sectors, namely Puskesmas with reproductive health programs related to primary dysmenorrhoea to improve the ability to live healthy and the health status of students. Further researchers should screen for primary dysmenorrhoea with clinical trials and should expand the coverage of research respondents and improve research results by controlling for other factors that influence this study by adding research variables such as knowledge, education level and age, primary dysmenorrhea in female adolescent in high school, in the presence of other variables and a larger age range, better research results will be obtained. 


\section{References}

Achmad, F. R., \& Sukohar, A. (2019). Perbedaan Derajat Kecemasan Antara Mahasiswa Tahap Akademik Tingkat Awal dengan Tingkat Akhir di Fakultas Kedokteran Universitas Lampung. Jurnal Medula, 9(1).

BKKBN. (2016). Materi Promosi dan Konseling Kesehatan Reproduksi.

BKKBN. (2019). Membantu Remaja Merencanakan Masa Depannya.

Calis. (2012). Prevalensi Dismenorea Cukup Tinggi Pada Remaja. Salemba Medika.

Chrisnawati, G. \& T. A. (2019). Aplikasi Pengukuran Tingkat Kecemasan Berdasarkan Skala Hars Berbasis Android. Jurnal Teknik Komputer, 5(2), 227-282.

Dahlan, S. (2015). Statistik Untuk Kedokteran dan Kesehatan. Epidemiologi Indonesia.

DEPKES, R. I. (2011). Kesehatan Remaja Problem dan Solusinya. Salemba Medika.

DPL, N., \& Gustaman, F. A. (n.d.). Kompilasi Artikel Kkn Unnes Bersama Lawan Covid-19 Kecamatan Lasem.

Fudyartanta, K. (2012). Psikologi kepribadian. Yogyakarta: Pustaka Pelajar.

Harnani, Y., Marlina, H., \& Kursani, E. (2015). Teori kesehatan reproduksi. Deepublish.

Lail Husnul. (2017). Hubungan Status Gizi,
Usia Menarche dengan Dismenore pada Remaja Putri Di SMK K Tahun Remaja dengan Kejadian Dismenore pada Siswi SMP X Bandung. Ilmu Keperawatan, II(I), 57-61.

Lubis, N. L. (2016). Psikologi Kespro. Wanita dan Perkembangan Reproduksinya: Ditinjau dari Aspek Fisik dan Psikologinya. Kencana.

Manuaba. (2010). Pengantar Kuliah Obstetri. EGC.

Mardjan, H. (2016). Pengaruh kecemasan pada kehamilan primipara remaja. Abrori Institute.

Narulita, A. E., \& NIM010810113. (2012). Hubungan Lama Menstruasi Dan Siklus Menstruasi Dengan Perubahan Kadar Hemoglobin Siswi Kelas Ii Smk Ypm 11 Wonoayu Sidoarjo.

Rahayu, R., Patimah, S., Rohmatin, E., Kunci, K., \& Penelitian, B. (2019). Pengaruh Minuman Jahe Merah Terhadap Penurunan Skala Nyeri Dismenorea Primer Pada Siswi Kelas VIII Di SMPN 10 Tasikmalaya Tahun 2018. Midwifery Journal, 5(02), 26-35.

Reeder, S. J., Leonie, L. M., \& Deborah, K. G. (2013). Keperawatan Maternitas Kesehatan Wanita, Bayi, dan Keluarga Volume 2 Edisi 18. Jakarat: $E G C$.

RI, P. D. dan I. K. K. (2019). Situasi Kesehatan Jiwa di Indonesia. https://pusdatin.kemkes.go.id/resourc es/download/pusdatin/infodatin/InfoD atin-Kesehatan-Jiwa.pdf.

Sinaga, E., Saribanon, N., Sa'adah, N., 
Salamah, U., Murti, Y. A., \& Trisnamiati, A. (2017). Buku: Manajemen Kesehatan Menstruasi.

Supriatin, E. (2014). Hubungan Kecemasan Remaja Dengan Kejadian Dismenorea Pada Siswi Smp X Bandung. Jurnal Keperawatan BSI, 2(1).

UGM, F, -K. (2020). Reportase Webinar Mengelola Kecemasan Pada Remaja Selama Masa Pandemi COVID-19. https://manajemencoviddirs.net/index.php/2020/04/16/reporta se-webinar-mengelola-kecemasanpada-remaja-selama-masa-pandemicovid-19-rabu-15-april-2020-pukul13-00-15-00/.

Wuryaningsih, Emi Wuri., et al. (2018). Buku Ajar Keperawatan Kesehatan Jiwa (1st ed.). UPT Percetakan \& Penerbitan Universitas Jember.

Zaini, M. (2019). Asuhan Keperawatan Jiwa Masalah Psikososial di Pelayanan Klinis dan Komunitas. Deepublish.

Saribanon, Nonon, et al. (2017). Manajemen Kesehatan Menstruasi. Universitas Nasional.

Supriatin, E. (2014). Hubungan Kecemasan Remaja dengan Kejadian Dismenore pada Siswi SMP X Bandung. Ilmu Keperawatan, II(I), 57-61.

UGM, F.-K. (2020). Reportase Webinar Mengelola Kecemasan Pada Remaja Selama Masa Pandemi COVID-19. https://manajemencoviddirs.net/index.php/2020/04/16/reporta se-webinar-mengelola-kecemasanpada-remaja-selama-masa-pandemi- covid-19-rabu-15-april-2020-pukul13-00-15-00/.

Wuryaningsih, Emi Wuri., et al. (2018). Buku Ajar Keperawatan Kesehatan Jiwa (1st ed.). UPT Percetakan \& Penerbitan Universitas Jember.

Zaini, M. (2019). Asuhan Keperawatan Jiwa Masalah Psikososial Pelayanan Klinis dan Komunitas. Deepublish. 